\title{
Primary cerebellar glioblastoma multiforme
}

\author{
Steven A. Levine ${ }^{1}$, Paul E. McKeever ${ }^{2}$ and Harry S. Greenberg ${ }^{3}$ \\ ${ }^{1,3}$ Department of Neurology, ${ }^{2}$ Department of Pathology, University of Michigan, Ann Arbor, Michigan \\ 48109, USA
}

Key words: cerebellar glioblastoma multiforme

\section{Summary}

Glioblastoma multiforme in adults arising in the cerebellum is a rare tumor, well documented in only 13 cases in the literature. We report a fourteenth case, an 80-year-old female, and reassess the clinical and CT aspects of this tumor based on a review of the world's literature. The median age of patients is 53 years with a median survival of three months, which is less than adult cerebral hemisphere malignant gliomas.

\section{Introduction}

Glioblastoma multiforme of the cerebellum is a rare tumor in adults [1-7]. All patients presenting with signs and symptoms referable to the posterior fossa with published histopathology of a Grade III or IV glioma arising de novo in the cerebellum are reviewed. We report the fourteenth case, and reassess the clinical and CT aspects of this tumor.

All published reports of adult cerebellar glioblastomas were reviewed $[1,3-5,8-24]$. The criteria for selection of our patients included: a) 16 years of age or older, b) published histopathology of a Grade III or IV cerebellar glioma without significant brainstem involvement (that would suggest primary brainstem origin), c) the cerebellum was the primary location of the glioblastoma multiforme, d) no previous history of a lower grade or benign juvenile cerebellar astrocytoma, and e) no previous history of metastatic disease to the cerebellum. Table 1 lists the detailed descriptions of the 14 cases. Our selection criteria allowed us to determine more accurately the clinical features and response to therapy.

\section{Case presentation}

A.G., an 80-year-old right handed white female, presented with an eight month history of intermittent blurred vision, syncope and lower extremity incoordination. Two months prior to admission she developed slurred speech and mild right-handed weakness. Three weeks prior to admission occipital headaches began, associated with nausea and vomiting. She denied vertigo, incontinence and sensory symptoms. There was no past history of cancer, alcohol abuse, thyroid, cerebrovascular, cardiac or neurologic disease. Examination revealed her speech to be slowed, slurred and dysrhythmic. Cranial nerve examination revealed third and sixth nerve palsies and right beating nystagmus on right lateral gaze. Gait was ataxic with dysmetria of all four limbs, more prominent on the right. Her legs were more ataxic than her arms. There was bilateral hyperreflexia greater on the left. Babinski signs were present bilaterally. Sensory exam was normal. Admission laboratories included normal serum chemistries, blood counts, chest X-ray, and EKG. Head CT scan without contrast, from another hospital, six months prior to admission was normal. Admission CT scan revealed a $5 \times 6 \mathrm{~cm}$ multilobular, cystic, non-homogeneously enhancing, midline cerebellar mass lesion (Fig. 1). Partial ventricular obstruction was present (not shown).

A posterior fossa craniotomy was performed with gross total resection of the lesion. The tumor was 
Table 1. Primary cerebellar glioblastoma multiforme in adults: Detailed description (summary and documentation of literature cases).

\begin{tabular}{|c|c|c|c|c|c|c|c|c|}
\hline Author & Year & Age & Sex & Location & Grade & Comments & $\begin{array}{l}\text { Diagnosis } \\
\text { \& therapy }\end{array}$ & $\begin{array}{l}\text { Course to } \\
\text { death }\end{array}$ \\
\hline Powell [4] & 1947 & 70 & M & LH & III-IV & & & 6 weeks \\
\hline Huntington [15] & 1965 & 32 & M & LH & III-?IV & High grade astrocytoma & & 3 weeks \\
\hline \multirow[t]{2}{*}{ Gross [13] } & 1969 & 49 & F & $\mathrm{V}$ & IV & & $\mathrm{Bx}$ & 3 months \\
\hline & & 64 & $\mathbf{M}$ & $\mathrm{LH}$ & IV & Leptomeningeal involvement & & 3 months \\
\hline Dohrman [1] & 1975 & 55 & F & $\mathrm{RH}$ & IV & $\begin{array}{l}\text { Associated AVM adjacent to } \\
\text { tumor + cerebellar hematoma }\end{array}$ & $\begin{array}{l}\mathrm{PR}+\mathrm{RT}+ \\
\text { steroids }\end{array}$ & 6 months \\
\hline \multirow[t]{2}{*}{ Luccarelli [18] } & 1980 & 34 & $\mathrm{~F}$ & $\mathrm{RH}$ & III-IV & & $\mathrm{PR}+\mathrm{RT}$ & $\begin{array}{l}- \text { (at least } \\
2 \text { years) }\end{array}$ \\
\hline & & 52 & M & $\mathrm{LH}$ & IV & & - & - \\
\hline Tibbs [23] & 1980 & 49 & $\mathrm{~F}$ & $\mathrm{RH}$ & IV & & $\begin{array}{l}\mathrm{PR}+\mathrm{RT}+ \\
\mathrm{CCNU}\end{array}$ & 2 months \\
\hline Auff [8] & 1981 & 54 & $\mathrm{~F}$ & $\begin{array}{l}\text { LH + medulla } \\
+ \text { pons }\end{array}$ & III-IV & $\begin{array}{l}\text { Primary hemisphere involve- } \\
\text { ment with partial invasion of } \\
\text { dorsolateral medulla }\end{array}$ & & $\begin{array}{l}\text { At least } \\
3 \text { months }\end{array}$ \\
\hline Escalona-Zapata [12] & 1981 & 51 & M & $\mathrm{V}+\mathrm{RH}+\mathrm{LH}$ & III-IV & & - & 2 weeks \\
\hline Kopelson [17] & 1982 & 60 & M & - & III & & $\mathrm{Bx}+\mathrm{RT}$ & 1 year \\
\hline Hegedus [14] & 1983 & 39 & $\mathrm{~F}$ & $\begin{array}{l}\mathrm{V}+\mathrm{R} \mathrm{H}+ \\
\text { pons }+ \text { medulla }\end{array}$ & III-IV & $\begin{array}{l}\text { Gemistocytes meningeal, in- } \\
\text { volement, primary cerebellar } \\
\text { involvement }\end{array}$ & $\begin{array}{l}\mathrm{PR}+\mathrm{RT}+ \\
\mathrm{IT} \mathrm{CT}\end{array}$ & $51 / 2$ years \\
\hline Zito $[24]$ & 1983 & 76 & $\mathrm{~F}$ & $\mathrm{RH}$ & IV & $\mathrm{Hx}$ breast $\mathrm{Ca}$ & PR & 2 months \\
\hline Levine & 1986 & 80 & $\mathrm{~F}$ & $\mathrm{~V}+\mathrm{RH}$ & IV & Anaplastic & $\mathrm{PR}+\mathrm{RT}$ & $\begin{array}{l}- \text { (at least } \\
3 \text { months) }\end{array}$ \\
\hline
\end{tabular}

LH = left cerebellar hemisphere; $\mathrm{V}=$ vermis; $\mathrm{RH}=$ right cerebellar hemisphere; $\mathrm{Bx}=$ biospy; $\mathrm{AVM}=$ arteriovenous malformation; $\mathrm{PR}=$ partial resection; $\mathrm{RT}=$ radiation therapy; $\mathrm{CCNU}=$ lomustine; ITCT $=$ intrathecal chemotherapy; $\mathrm{Hx}=\mathrm{history}$ of; $\mathrm{Ca}=\mathrm{cancer}$.

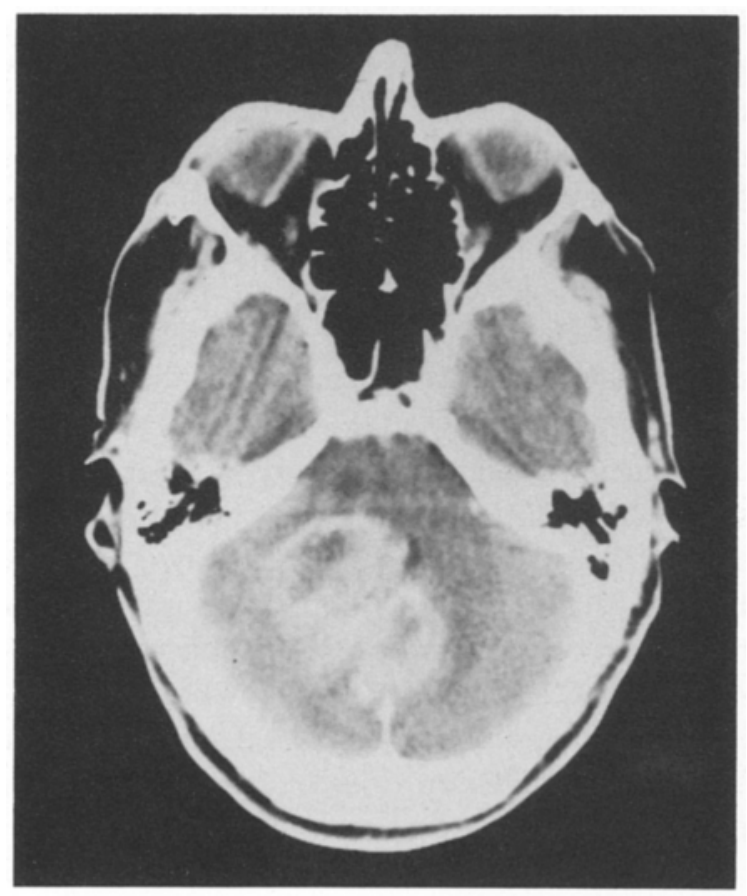

composed of neoplastic astrocytes (Fig. 2). Regions of the tumor were crowded with a high density of cells with markedly pleomorphic and hyperchromatic nuclei which touched and indented each other. Tumor giant cells (Fig. 2) were common. Vascular endothelial proliferation was evident in both reduplication of lumens (Fig. 3) and by vessels thickened by cells proliferating in their walls. Regional and individual cellular necrosis were abundant (Fig. 4). Some vessels contained periadventitial and other contained subendothelial mononuclear cells. Intravascular thrombi were present in a few vessels.

Fig. 1. Head computed tomography after contrast infusion: A contrast enhancing, $5 \times 6 \mathrm{~cm}$ multilobular mass is seen situated in the midline and to the right of midline within the cerebellar substance displacing the fourth ventricle to the left. There are nonenhancing areas centrally. No other lesions were seen and there was a moderate degree of supratentorial ventricular enlargement. 


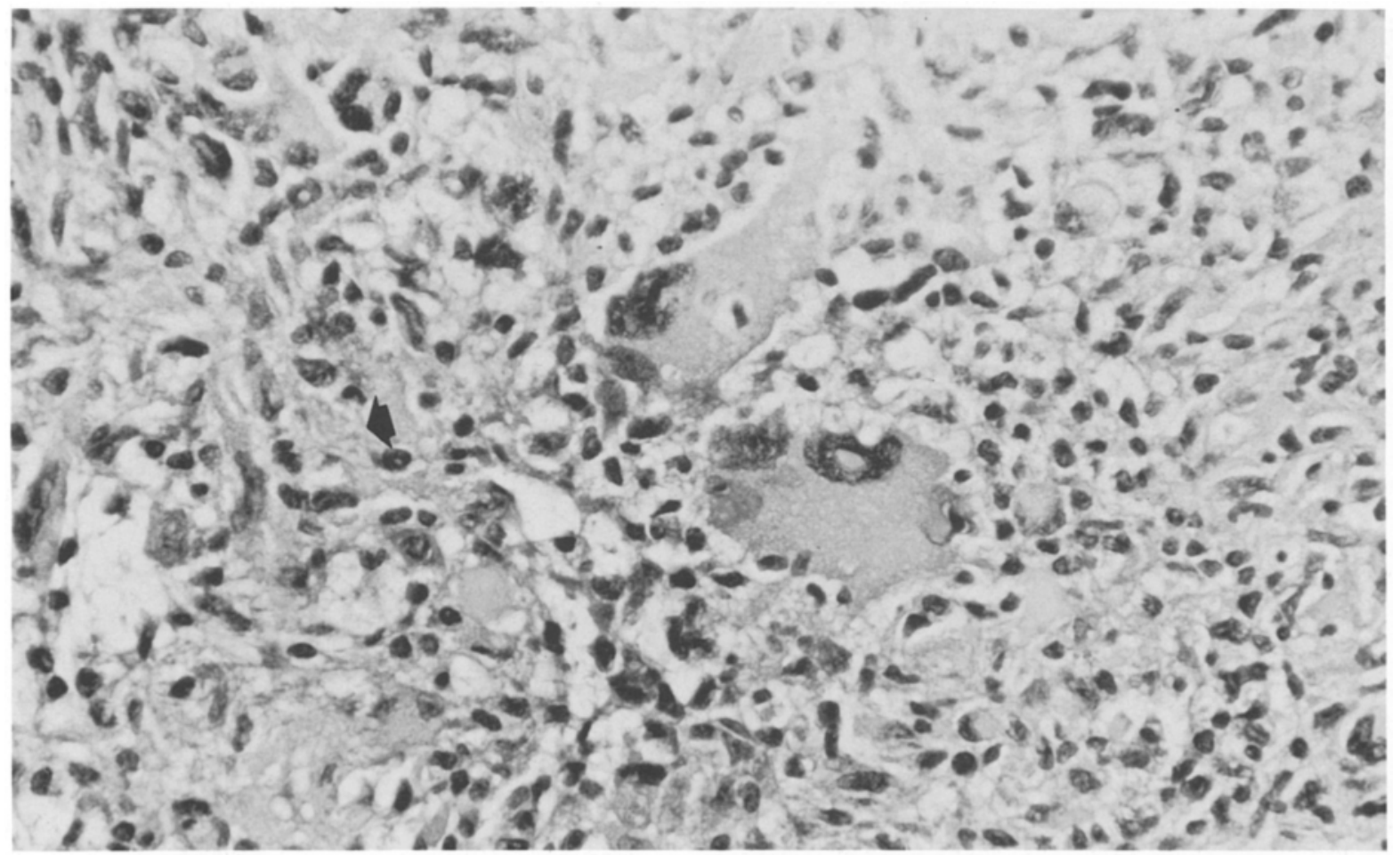

Fig. 2. Fibrillary processes (arrow) are features of the neoplastic glia composing the parenchyma of this glioblastoma multiforme. Multinucleated giant cells are present. Hematoxylin and eosin stain. Magnification X600.

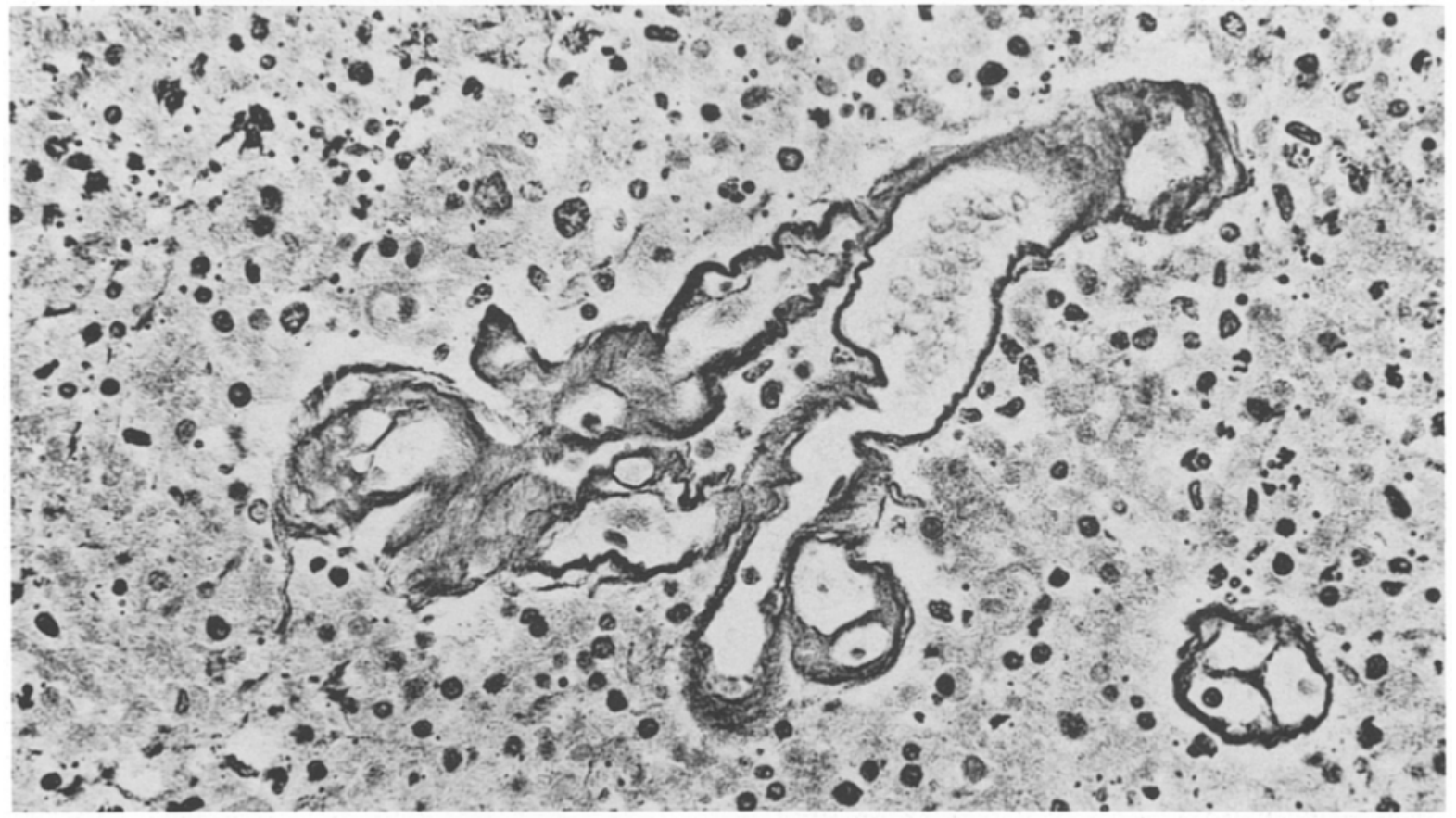

Fig. 3. Multiple lumens were produced by endothelial proliferation of a vessel within the glioblastoma. The lumens are light are outlined by the darkly stained walls which contain reticulin fibers. The surrounding parenchyma is negative for reticulin and shows scattered nuclei and debris. Wilder's silver stain for reticulin. Magnification X600. 


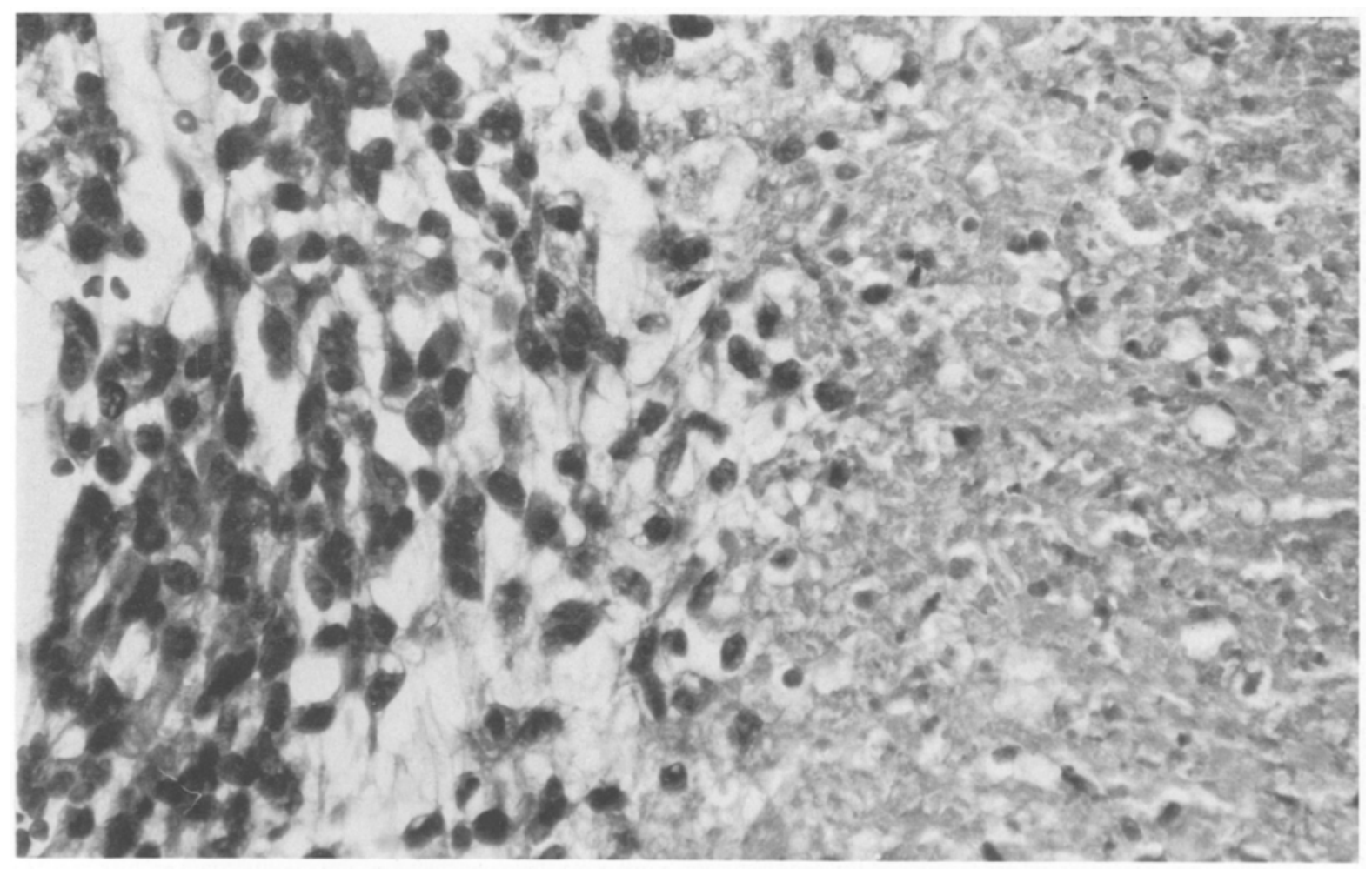

Fig. 4. Extensive proliferation of neoplastic glia is evident by the darkly stained nuclei which crowd and indent one another at the edge of a uniformly lighter stained region of tumor necrosis. Hematoxylin and eosin. Magnification X600.

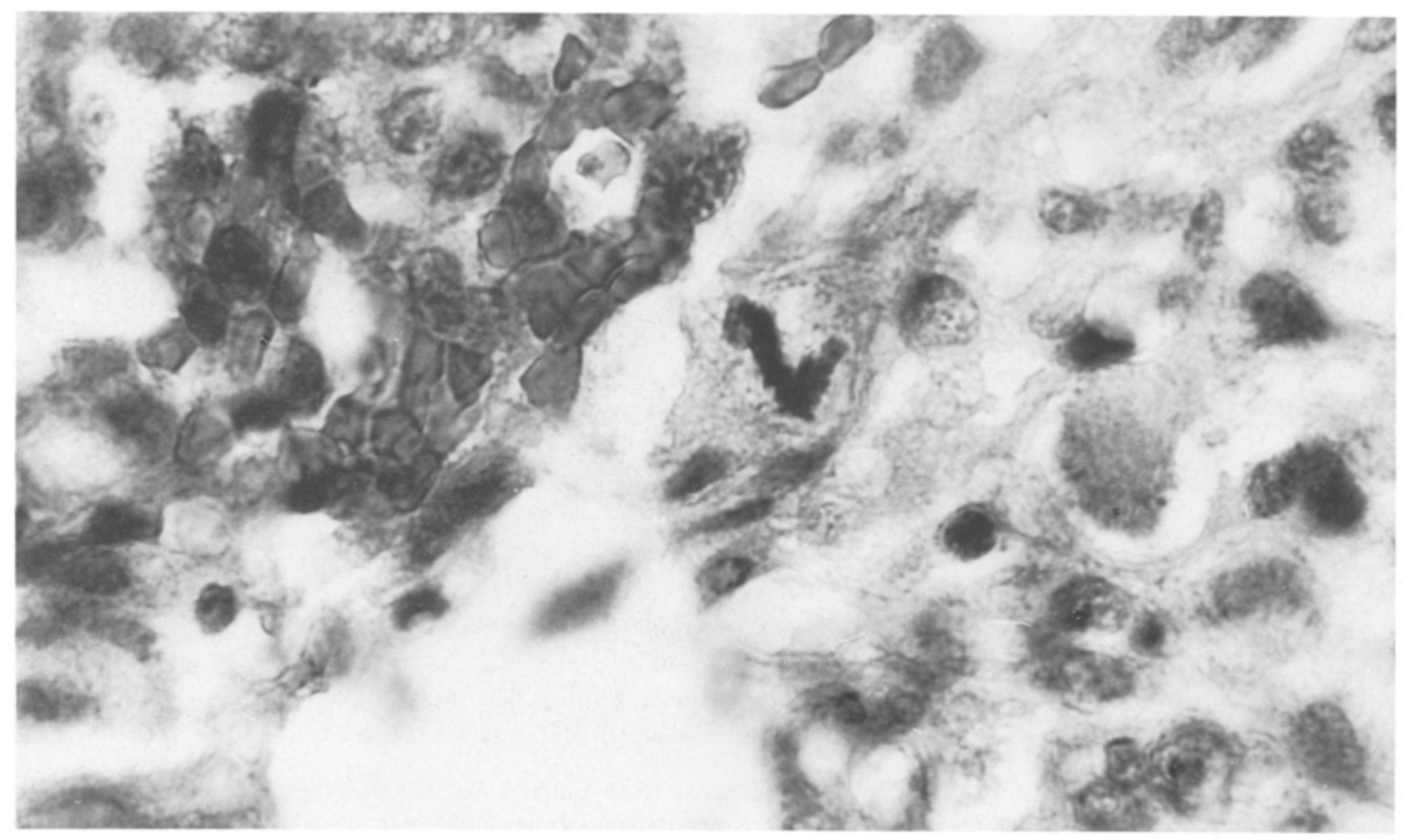

Fig. 5. Abnormal mitotic spindle almost produces a "V" shape within this neoplastic glial cell. This cell is near the edge of a hypercellular region at the left of the field which contains numerous dark and crowded nuclei. Hematoxylin and eosin. Magnification X950. 


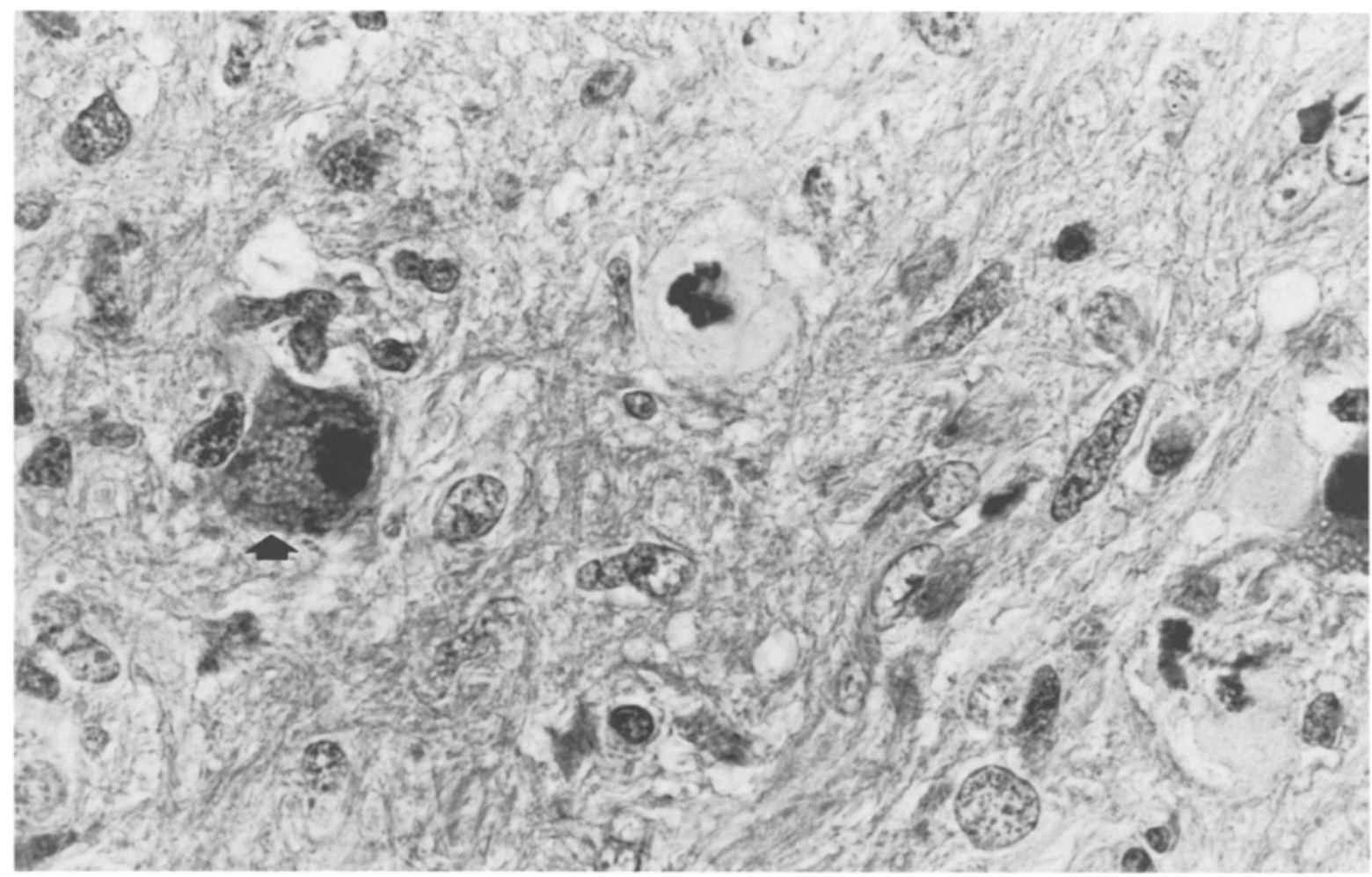

Fig. 6. Deep molecular layer of cerebellum tangential to edge of Purkinje cell layer is infiltrated by neoplastic glia. Two glioma cells are indenting a dying Purkinje cell (arrow) which has a pyknotic nucleus. Two other cells are in mitosis. Hematoxylin and eosin. Magnification X950.

Mitoses were present in numbers up to three per $40 \mathrm{X}$ objective microscopic field, and some were abnormal (Figs. 5 and 6). The glioblastoma had a diffuse margin and invaded surrounding cerebellar folia. There was a tendency toward satellitosis of Purkinje cells by neoplastic glia (Fig. 6). Postoperatively, she became obtunded and on reoperation later that day, a tumor bed hematoma was evacuated. She did well postoperatively and received 5000 rads of radiation therapy to the tumor bed.

\section{Discussion}

Primary cerebellar glioblastoma multiforme in adults is distinctly rare [1-7]. Since 1931 when first reported by Cushing [8], there have been 13 cases with published histopathology $[1,4,9,15,17,18,23$, 24]. The median age of patients including our case is 53 years (range $32-80$ ). Eight cases occurred in women and six in men. In a review of 32 cases (cases accepted without published histology) and the addition of a single new case, Dohrman and Dunsmore [1] found the male to female ration was $2: 1$; however, children accounted for one-third of their cases. The median survival in our series of three months (range 2 weeks to 5.5 years) is shorter than the one year figure reported previously by Dohrman [1] who included children, and is significantly less than the one year survival reported with treated cerebral hemisphere malignant gliomas [25]. This may be due to the relatively smaller area of the posterior fossa where a smaller mass can exert local and remote pressure effects on the brainstem.

Four of the 14 cases had vermal or midline involvement $(29 \%)$ and those patients had a median survival of approximately 3 months (range 2 weeks to 5.5 years), not differing from patients with only cere- 
bellar hemisphere involvement (median survival 3 months, range 3 weeks to 2 years).

Four cases had CT correlation [3, 23, 24]. Three of the four CT scans showed a hemisphere cerebellar mass while the fourth was vermian. Zito et al. [24] reported a difference in CT appearance between primary cerebellar glioblastoma and metastatic disease to the cerebellum. Metastatic disease typically had more peri-tumoral edema, mass effect on the fourth ventricle and hydrocephalus. They concluded that "the presence of a large cerebellar mass with little mass effect and lack of peri-tumoral edema should suggest cerebellar glioma as the prime diagnostic consideration despite its rare occurrence" [24]. We feel that metastatic disease to the cerebellum is a more likely diagnosis even when CT reveals a mass without peri-tumoral edema because of a much higher incidence of cerebellar metastasis.

In conclusion, there is no explanation for the rarity of adult primary cerebellar glioblastoma multiforme. Based on the relative weight the cerebellum is $10 \%$ of the whole brain, we could expect $10 \%$ of all malignant gliomas to occur in the cerebellum. This report extends the age range to octogenarians.

\section{References}

1. Dohrman GJ, Dunsmore RH: Glioblastoma multiforme of the cerebellum. Surg Neurol 3:219-223, 1975

2. Gilman S, Bloedel JR, Lechtenberg R: Disorders of the cerebellum. Contemporary Neurology Series. Vol. 21. FA Davis Co, Philadelphia, 1981

3. Miller EM, Mani RL, Townsend JJ: Cerebellar glioblastoma multiforme in an adult. Surg Neurol 5:341-343, 1976

4. Powell CB: Primary glioblastoma multiforme of the cerebellum: Report of a case. J Neuropathol Exp Neurol 6:279-285, 1947

5. Steinberg GK, Shuer LM, Conley FK, Hanberry JW: Evolution and outcome in malignant astroglial neoplasms of the cerebellum. J Neurosurg 62:9-17, 1985

6. Zulch KJ: Brain tumors: Their biology and pathology. Springer, New York, 1965

7. Russell DS, Rubenstein LJ: Pathology of tumor of the nervous system, Ed. 4. Williams \& Wilkins, Baltimore, 1977, pp $183-195 ; 248-254$

8. Auff E, Vass K: Cerebellar glioblastoma presenting clinically as Wallenberg's syndrome. Arch Psychiatr Nervenkr 230:361-364, 1981

9. Budka H, Wober G: Primary glioblastoma of the cerebellum: Report of a case associated with multifocal dysplastic glial changes. Acta Neurochir 31:115-121, 1974

10. Cushing $\mathrm{H}$ : Experience with the cerebellar astrocytomas. Surg Gyn/Obstetr 52:129-204, 1931

11. Davis L, Marting J, Goldstein L: A study of 211 patients with verified glioblastoma multiforme. J Neurosurg 6:33-45, 1949

12. Escalona-Zapata J, Salinero E, Lacruz C: Malignant cerebellar gliomas. Report of 4 cases with special reference to tissue culture study. J Neurosurg Sci 25(2):95-104, 1981

13. Gross SW, Cohen R, Panichavantana S: Cerebellar glioblastomas. J Mt Sinai Hosp NY 36(2):123-129, 1969

14. Hegedus K, Molnar P: Primary cerebellar glioblastoma multiforme with an unusually long survival. Case report. J Neurosurg 58:589-592, 1983

15. Huntington Jr RW, Cummings KL, Moe TI, O'Connell HV, Wyber R: Discovery of primary intracranial neoplasms at medicolegal autopsies. Cancer 18:117-123, 1965

16. Kleinmann GM, Schoene WC, Walshe TM III, Richardson G: Malignant transformation in benign cerebellar astrocytoma. J Neurosurg 49:111-118, 1978

17. Kopelson G: Cerebellar glioblastoma. Cancer 50:308-311, 1982

18. Luccarelli G: Glioblastoma multiforme of the cerebellum: Description of three cases. Acta Neurochir 53:107-116, 1980

19. Masucci EF, Ferrero AA, Kurtzke JF, Fox JL: Glioblastoma multiforme involving the posterior fossa: Case report and review of literature. Dis Nerv Syst 27:47-51, 1966

20. Pang D, Ashmead JW: Extraneural metastasis of cerebellar glioblastoma multiforme. Neurosurgery 10:252-257, 1982

21. Ringertz N: Cerebellar astrocytoma. J Neuropath Exp Neurol 10:343-367, 1951

22. Tateishi J, Kono M, Murakami M: Clinicopathological study on an adult case of cerebellar glioma: A case of anaplastic medullo-glioblastoma. Brain-Nerve (Tokyo) 22(2):183-189, 1970

23. Tibbs PA, Mortara RH: Primary glioblastoma multiforme of the cerebellum. A case report. Acta Neurochir 52:13-18, 1980

24. Zito JL, Siva A, Smith TW, Leeds M, Davidson R: Glioblastoma of the cerebellum. Computed tomographic and pathologic considerations. Surg Neurol 19:373-378, 1983

25. Walker MD, Green SB, Byar DP, Alexander E, Botzdorf V, Brooks WH, Hunt WE, MacCarty CS, Mahaley MS, Menley J, Owens G, Ransohoff J, Robertson JT, Shapiro WR, Smith KR, Wilson CB, Strike TA: Randomized comparisons of radiotherapy and nitrosoureas for the treatment of malignant glioma after surgery. N Engl J Med 303:1323-1329, 1980

Address for offprints: Harry S. Greenberg, Department of Neurology, University of Michigan Hospitals, 1914/0316 Taubman Center, Ann Harbor, MI 48109-0316, USA 